\title{
INCIDENCE OF LISTERIA SPECIES IN SOME DAIRY PRODUCTS IN BENI-SUEF GOVERNORATE
}

\author{
SAADIA H.H. ELSHINAWAY ${ }^{1}$; ARAFA M.S. MESHREF ${ }^{1}$; MOHAMED M.A. ZEINHOM ${ }^{1}$ \\ and DALIA A.A. HAFEZ ${ }^{2}$ \\ ${ }^{1}$ Department of Food Hygiene, Faculty of Veterinary Medicine, Beni-Suef University, Egypt. \\ ${ }^{2}$ Animal Health Research Institute.
}

Received: 19 October 2016; Accepted: 21 November 2016

\begin{abstract}
The present study was conducted to investigate the prevalence of Listeria spp. in some dairy products. A total of 240 samples of fresh cream, ice cream, butter milk cheese, Kareish cheese, Talaga cheese and yoghurt (40 of each) were collected randomly from different supermarkets, retail outlets and other markets outlets in Beni-Suef Governorate, Egypt. Out of 240 samples, 24(10\%) were positive for Listeria species. The occurrence of Listeria spp. in fresh cream, ice cream, butter milk cheese and Kareish cheese was 6(15\%), $8(20 \%), 5(12.5 \%)$ and $5(12.5 \%)$ respectively, while Listeria species couldn't be detected in any of Talaga cheese and yoghurt samples. The most prevalent species was L.grayii (45.83\%), followed by L.monocytogenes (33.33\%), and L.welshimeri $(12.51 \%)$ and L. innocua $2(8.33 \%)$. All 8 L.monocytogenes isolates showed the presence of the hly A gene suggesting the possibility of danger of food borne listeriosis among dairy products consumers. In conclusion, the results of this study emphasize the need forapplying more strict hygienic control measures especially during processing, storage and marketing of dairy products.
\end{abstract}

Key words: Listeria spp., Listeria monocytogenes, Dairy products, PCR assay.

\section{INTRODUCTION}

Milk and dairy products, because of their nutritional value, are suitable for development of microorganisms including pathogenic bacteria as Listeria species (Kasalica et al., 2011; El Marnissi et al., 2013 and Abd El Tawab et al., 2015).

Listeria species are ubiquitous bacteria, well adapted in the environment and can be isolated from soil, vegetables and natural waters as well as from healthy animal and man (Roberts and Weidmann, 2003; Cocolin et al., 2005 and Liu 2008). In this manner contaminate milk and production plants (Leite et al., 2006). Among the species of the genus Listeria, only L. monocytogenes is considered as one of the most significant food borne pathogen that induceserious and potentially life threatening illness known as listeriosis in humans and animals (Ryser and Marth, 2007 and Rahimi et al., 2012). However occasional human infection due to L.ivanovii and L.seeligeri has also been reported (Gilot and Content 2002).

Corresponding author: Dr. DALIA A.A. HAFEZ

E-mail address: dalia hafez@yahoo.com

Present address: Department of Food Hygiene, Faculty of Veterinary Medicine, Beni-Suef University, Egypt
Listeriosis has been recognized as one of the serious emerging bacterial zoonitic diseases. Several outbreaks and sporadic cases of listeriosis primarily associated with consumption of contaminated milk, soft or semi soft cheeses, uncooked and ready to eat foods, unwashed raw vegetables and fruits (Oliver et al., 2005; Swaminathan and Gerner-Smidt, 2007; Rahimi et al., 2010; Kevenk and Gulel, 2016).

Listeriosis can be life-threatening for newborns, elderly and immuno - compromised individuals (McLauchlin et al., 2004 and Rahimi et al., 2012). It may be ranged from non invasive febrile gastroenteritis or influenza like symptoms to persons with no predisposing conditions (Aureli et al., 2000) to serious invasive sever symptoms which may lead to septicemia, meningitis and abortion with high mortality rate of 20-30\% (Gandhi and Chikindas, 2007; Swaminthan et al., 2007; Shamloo et al., 2015; Kevenk and Gulel, 2016).

In dairy industry, many problems associated with $L$. monocytogenes contamination are related to minimally processed or post pasteurization contamination from plant environments (Gougouli et al., 2008; Rosshaug et al., 2012 and Olszewska et al., 2015). 
L.monocytogenes has the ability to survive or even grows in a wide range of adverse environmental conditions (Begley et al., 2010 and Cheng et al., 2015) such as refrigeration temperatures, high acidity and salinity and reduced water activity (Gandhi and Chikindas, 2007; Ahmed et al., 2014) makes it a potential hazard in milk and other dairy products.

Therefore, the present study was carried out to satisfy an urgent need to provide data about the presence of Listeria species in some dairy products in Beni-Suef governorate and to clarify the virulence of L.monocytogenes isolated from dairy products.

\section{MATERIALS AND METHODS}

\section{Collection of samples:}

- A total of two hundred and forty samples of fresh cream, ice cream, butter milk cheese, kareish cheese, yoghurt and talaga cheese (40 of each) were collected from different supermarkets, retail outlet and other markets outlets in Beni-Suef governorate, Egypt.

- All samples were aseptically collected and transferred into individual sterile bags or flasks then transported to the laboratory in insulated coolers containing cold packs and were analyzed immediately.

Isolation and identification of the Listeria species: The isolation of Listeria species is adopted according to (Roberts and Green wood, 2003). About $25 \mathrm{ml} / \mathrm{g}$ of each sample was aseptically homogenized in $225 \mathrm{ml}$ of listeria selective enrichment broth (CM0862, Oxoid) supplemented with listeria selective enrichment agents (nalidixic acid, acriflavine and cyclohexamide) (SR0141, Oxoid) and incubated in $30^{\circ}$ Cfor 24-48 h'. Aloopful of the incubated broth was streaked onto oxford listeria selective agar (CM0856, Oxoid) supplemented with listeria selective supplement (SR0140, Oxoid) which incubated for 48 h at $30^{\circ} \mathrm{C}$. The typical greyish green to brownish green colored colonies with black haloes of 1-3 mmin diameter of aesulin hydrolysis were presumed to be Listeria.

Five presumptive Listeria colonies were picked from each plates of selective agar and streaked ontotrypticasesoya agar (CM0131, Oxoid) containing $\left(0.6 \%\right.$ yeastextract) then incubated at $30^{\circ} \mathrm{C}$ for $24 \mathrm{~h}$ for biochemical identification. Non spore forming, Gram positive coccobacilli isolates were tested for catalase test, umbrella growth in motility test medium at $25^{\circ} \mathrm{C}$, nitrate reduction, MR/VP test, B.haemolysis activity, CAMP test (synergistic lyses of red blood cells) against $S$. aureus and acid production from fermentation of glucose, rhamnose, xylose and mannitol.

\section{Detection of Listeria monocytogenes (hly A gene) by PCR technique:-}

Listeria monocytogenes were screened for the presence of Listeriolysin O (hlyA) gene.

The primers used in the study (Aurora et al., 2007)

\begin{tabular}{lcccc}
\hline Primers & Target gene & Length & Primer sequence & $\begin{array}{c}\text { Amplification product } \\
(\mathrm{bp})\end{array}$ \\
\hline hlyA-F & hlyA & 24 & 5' GCAGTTGCAAGCGCTTGGAGTGAA 3' & 456 \\
\hline hlyA-R & hlyA & 24 & 5' GCAACGTATCCTCCAGAGTGATCG 3' & 456 \\
\hline
\end{tabular}

Extraction Procedure: (QIA amp DNA Mini Kit):

- $1.5 \mathrm{ml}$ of enriched broths was taken into microcentrifuge tubes and bacteria were pelleted by centrifugation at $8000 \mathrm{rpm}$ for $5 \mathrm{~min}$. Re-suspend pellet in PBS to a final volume of $200 \mu \mathrm{l}$. $20 \mu \mathrm{l}$ QIAGEN protease or proteinase K and $200 \mu$ l buffer $\mathrm{AL}$ were added and mixed for $15 \mathrm{~S}$. followed by incubation at $56^{\circ} \mathrm{C}$ for $10 \mathrm{~min} .200 \mu \mathrm{l}$ ethanol (96$100 \%$ ) were added and mixed again for $15 \mathrm{~S}$.

- Carefully the mixture was applied and centrifuged at $(8000 \mathrm{rpm})$ for $1 \mathrm{~min}$. The QIA amp Mini spin column was placed in a clean $2 \mathrm{ml}$ collection tube (provided) and discarded the tube containing the filtrate. The QIA amp Mini spin column was opened and $500 \mu \mathrm{l}$ buffer AW1was added and centrifuged at (8000 rpm) for $1 \mathrm{~min}$. The QIA amp Mini spin column was placed in a clean $2 \mathrm{ml}$ collection tube and discarded the tube containing the filtrate. $500 \mu \mathrm{l}$ buffer AW2was added and centrifuged at full speed (14.000rpm) for $3 \mathrm{~min}$.

The QIA amp column was placed in a new $2 \mathrm{ml}$ collection tube and discarded the old collection tube with the filtrate, then centrifuged at full speed for 10 min. The QIA amp column was placed in a clean tube (not provided) and discarded the collection tube containing the filtrate. Carefully the QIA amp column was opened and added 100-200 $\mu$ l buffer AE or distilled water then incubated at $\left(15-25^{\circ} \mathrm{C}\right)$ for 3 $\mathrm{min}$ and centrifuged at $(8000 \mathrm{rpm})$ for $1 \mathrm{~min}$. 
Spectrophotometer:-

The concentration of DNA was measured by using spectrophotometer.

PCR Procedures:

There agents of PCR reaction were set up in a tube:

1 - $25 \mu$ lof $2 \mathrm{X}$ of PCR Master Mix containing: enzyme (DNA polymerase, Taq); dNTPs (A, T, G,
C) and buffer (50 mMKCl; $10 \mathrm{mMTris}-\mathrm{HCl} ; 1.5 \mathrm{mM}$ $\mathrm{MgCl} 2)$.

2 - 20 pmolprimer.

3 - 30-50 ngsample (DNA)

4 - If needed water DNA ase free water and 50 $\mu$ ltotalreaction volume.

Amplification was done in the following condition shown in the next table.

Cycling conditions used for the primers

\begin{tabular}{ll}
\hline Steps & Time and Temper \\
\hline $\begin{array}{l}\text { - Initial denaturation } \\
\text { - Denaturation }\end{array}$ & $95^{\circ} \mathrm{C}$ for $3 \mathrm{~min}$ \\
- Annealing & $94^{\circ} \mathrm{C}$ for $40 \mathrm{sec}$ \\
- Extension & $41^{\circ} \mathrm{C}$ for $40 \mathrm{sec}$ \\
- Final extension & $72^{\circ} \mathrm{C}$ for $1 \mathrm{~min}$ \\
- Hold & $72^{\circ} \mathrm{C}$ for $10 \mathrm{~min}$ \\
& $4^{\circ} \mathrm{C}$
\end{tabular}

The amplified DNA fragments were resolved by agarose gel electrophoresis, stained with ethidium bromide (e $(0.5 \mu \mathrm{g} / \mathrm{ml})$ and the gels can be screened and pictured under UV light.

\section{RESULTS}

The genus Listeria is ubiquitous in the surrounding environment and therefore, control of this organism during food processing is difficult (Kells and
Gilmour, 2004). Many outbreaks of $L$. monocytogenes infection associated with consumption of milk and dairy products have been reported by CDC (Centers for Disease Control and prevention) (2011) and Gaulin et al. (2012).

Table 1: Incidence of Listeria spp. in some dairy products

\begin{tabular}{cccc}
\hline \multirow{2}{*}{ Products } & \multirow{2}{*}{ No of samples } & \multicolumn{2}{c}{ Positive samples (\%) } \\
\cline { 2 - 4 } & & No of positive samples & $\mathbf{1 5 \%}$ \\
\hline Fresh cream & 40 & 8 & $20 \%$ \\
\hline Ice cream & 40 & 5 & $12.5 \%$ \\
\hline Butter milk cheese & 40 & 5 & $12.5 \%$ \\
\hline Kareish cheese & 40 & 0 & 0 \\
\hline Talaga cheese & 40 & 0 & 0 \\
\hline Yoghurt & 40 & 24 & $10 \%$
\end{tabular}

Table 2: Distribution of Listeria species isolated from various dairy products samples

\begin{tabular}{|c|c|c|c|c|c|c|c|}
\hline $\begin{array}{l}\text { Type of } \\
\text { product }\end{array}$ & L.monocytogenes & L.welshimeri & L. grayii & L. innocua & L. ivanovii & L.seeligeri & Total \\
\hline Fresh cream & $2(8.33 \%)$ & $\mathbf{0}$ & $4(16.66 \%)$ & $\mathbf{0}$ & $\mathbf{0}$ & $\mathbf{0}$ & $6(25 \%)$ \\
\hline Ice cream & $3(12.5 \%)$ & $1(4.16 \%)$ & $3(12.5 \%)$ & $1(4.16 \%)$ & $\mathbf{0}$ & $\mathbf{0}$ & $8(33.34 \%)$ \\
\hline $\begin{array}{c}\text { Butter milk } \\
\text { cheese }\end{array}$ & $2(8.33 \%)$ & $1(4.16 \%)$ & $1(4.16 \%)$ & $1(4.16 \%)$ & $\mathbf{0}$ & $\mathbf{0}$ & $5(20.83 \%)$ \\
\hline Kareish cheese & $1(4.16 \%)$ & $1(4.16 \%)$ & $3(12.5 \%)$ & $\mathbf{0}$ & $\mathbf{0}$ & $\mathbf{0}$ & $5(20.83 \%)$ \\
\hline Talaga cheese & 0 & 0 & 0 & $\mathbf{0}$ & $\mathbf{0}$ & $\mathbf{0}$ & $\mathbf{0}$ \\
\hline Yoghurt & $\mathbf{0}$ & $\mathbf{0}$ & $\mathbf{0}$ & $\mathbf{0}$ & $\mathbf{0}$ & $\mathbf{0}$ & $\mathbf{0}$ \\
\hline Total & $8(33.33 \%)$ & $3(12.5 \%)$ & $11(45.83 \%)$ & $2(8.33 \%)$ & $\mathbf{0}$ & $\mathbf{0}$ & $24(100 \%)$ \\
\hline
\end{tabular}


In the present study, of the 240 samples of some dairy products, 24(10\%) were positive for the presence of Listeria species (Table 1). The prevalence of Listeria spp. in fresh cream, ice cream, butter milk cheese and Kareish cheese was $6(15 \%), 8(20 \%), 5(12.5 \%)$ and $5(12.5 \%)$ respectively, whereas ice cream was the most contaminated product tested. Listeria spp. couldn't be isolated from any of Talaga cheese and yoghurt samples.

From the inspection of Table 2, L. grayii with $(45.83 \%)$ was the most prevalent species isolated followed by L. monocytogenes with (33.33\%), L.welshimeri with $(12.51 \%)$ and L. innocua $(8.33 \%)$, while other species of Listeria pathogen couldn't be isolated from any of the examined samples. All the eight isolates of listeria monocytogenes which identified biochemically were genetically confirmed by PCR technique represented in $2(5 \%), 3(7.5 \%)$, $2(5 \%)$ and $1(2.5 \%)$ in fresh cream, ice cream, butter milk cheese and Kareish cheese respectively (Table 3 and Fig1)

Table 3: Results of PCR method

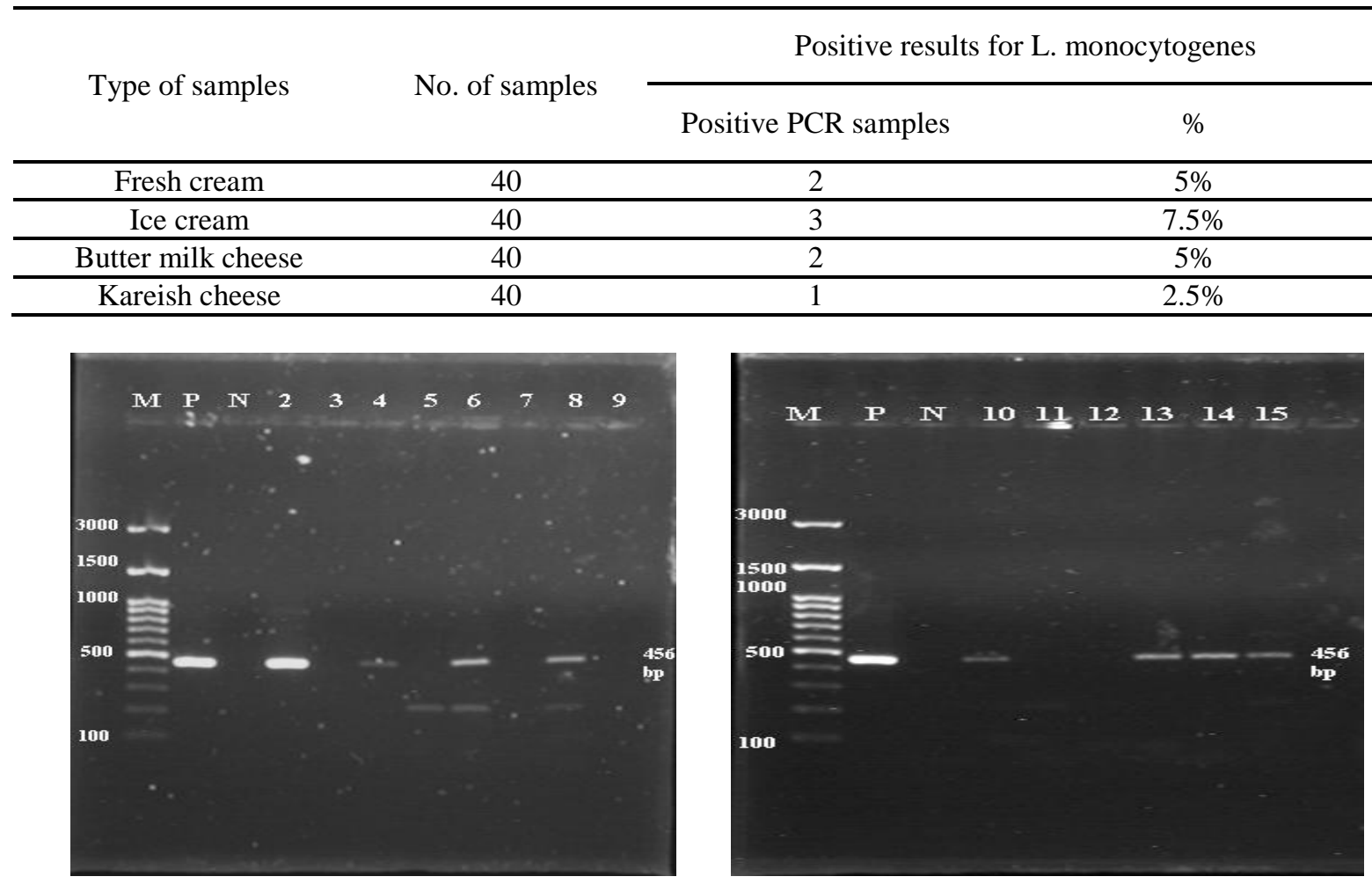

Fig. 1: Agarose gel electrophoresis of hylA gene specific for L.monocytogenes by enrichment PCR method

Lane M: DNA marker Ladder (100-3000 bp)

Lane P: Control positive for (hlyA) at 456 bp

Lane N: Control negative

Lane 2-15: Isolates of Listeria monocytogenes which biochemically identified

\section{DISCUSSION}

In the current study, 6(15\%) of fresh cream samples were contaminated with Listeria spp., whereas $L$. grayii was the most frequent $4(16.66 \%)$ species identified in fresh cream samples followed by L.monocytogenes which detected in only $2(8.33 \%)$ of the examined samples. Higher rate of contamination with Listeria spp. 10(20\%) was obtained by Metwally and Ali, (2014), while Shamloo et al. (2015) reported low rate of contamination $3(11.11 \%)$ with Listeria spp.
Unlike to our results, Gunasena et al. (1995); El Habib et al. (2014) and Shamloo et al. (2015) couldn't detect L.monocytogenes in all examined fresh cream samples. The occurrence of Listeria spp. in fresh cream could be due to the use of raw milk, environmental contamination and insufficient hygiene during production.

Ice cream is one of the widely accepted dairy products that dominate interest of large segments of population (Anonymous 2012). Frequent occurrence of L. monocytogenes in ready to eat foods as ice cream as a result of its psychrotrophic genetic ability, implies increased public health risk hazard. The present study revealed that out of 40 examined ice 
cream samples, $8(20 \%)$ samples yielded growth of Listeria species. The prevalence of L. monocytogenes, $L$. welshimeri, $L$. grayii and $L$. innocua detected in ice cream samples in this study were $3(12.5 \%)$, $1(4.16 \%), 3(12.5 \%)$ and $1(4.16 \%)$, respectively. Ice cream samples showed the highest incidence of Listeria species among all examined samples.

Nearly similar results (19.04\%) was reported by Shamloo et al. (2015), while prevalence of Listeria spp. was much higher as compared to those observed by Wahba (2002); Rahimi et al. (2012); Akya et al. (2013); Muhammed et al. (2013) and Abd El Tawab et al. (2015). High incidence of Listeria spp. was recorded by Molla et al. (2004) and Mengesha et al. (2009).

Contrary to the postulated results, Listeria spp. couldn't be isolated from examined ice cream samples in studies performed by Dhanashree et al. (2003); Ambily and Beena (2012); El Habib et al. (2014); Kevenk and Gulel (2016). On the other hand, Muhammed et al. (2013); Akya et al. (2013); Metwally and Ali (2014) failed to isolate $L$. monocytogenes from the examined ice cream samples.

The higher incidence of Listeria spp. in ice cream samples could be attributed to the contamination of raw milk, low quality of ingredients used, use of polluted water supplies and lack of hygienic measures during processing and handling besides the absence of pasteurization, especially in case of small scale produced ice cream.

Egyptian cheese has a long history as an important part of the modern Egyptian diet with an extended shelf life and is more self stable over the raw material used in the production (Fox et al., 2004). Soft cheeses have been involved in both outbreaks (Goulet et al., 1995) and several sporadic cases (Farber et al., 1990) of listeriosis and are thus considered as risk products.

The present study was conducted to detect the prevalence of Listeria spp. and L.monocytogenes in 3 types of soft cheeses, Kareish cheese, butter milk cheese and Talaga cheese, whereas the high moisture content of almost $50 \%$ of these cheeses make them more suitable for growth of microorganisms (Metwally and Ali, 2014).

Listeria spp. was identified in $5(12.5 \%)$ of each Kareish cheese and butter milk cheese, while none of the samples of Talaga cheese was found to contain Listeria microorganisms.

The results of Talaga cheese in the present study are in agreement with the results of Atil et al. (2011); Akya et al. (2013) and Ahmed (2013). In the studies conducted by Kevenk and Gulel (2016); Abd El Tawab et al. (2015); Wijendra et al. (2014),
L.monocytogenes was isolated with very low incidence of $1(5 \%), 1(2 \%)$ and $4(5 \%)$ in the examined white cheese samples.

L. grayii was the most prevalent species isolated from Kareish cheese $(12.5 \%)$, whereas L.monocytogenes and L.welshimeri were detected in $(4.16 \%)$ for each. While in butter milk cheese L. grayii, $L$. monocytogenes, L. welshimeri and L. innocua were isolated from $4.16 \%, 8.33 \%, 4.16 \%$ and $4.16 \%$, respectively.

In the study performed by Metwally and Ali (2014), Listeria spp. was detected in $11(22 \%)$ of the examined butter milk cheese from which $8 \%$ L.grayii followed by $2 \%$ L.innocua and $1 \%$ L.ivanovii, while L.monocytogenes, L.welshimeri and L.seeligeri couldn't be isolated from any of the examined samples.

On the other hand, high incidence of Listeria spp. in Kareish cheese was detected by Metwally and Ali (2014); Meshref et al. (2015), while lower incidence was reported by Derra et al. (2013); Muhammed et al. (2013); Ismail et al. (2014); Abd El Tawab et al. (2015)

In a study performed by Rahimi et al. (2010), Listeria spp. and L.monocytogenes were isolated in 18.9 and 10 of 90 cheese samples, while in another study conducted by Arslanand Ozdemir (2008) Listeria spp. was detected in $33.1 \%$ of homemade white cheese samples.

The type and composition of cheese, $\mathrm{pH}, \%$ of moisture, $\%$ of salt, ripeness of cheese, storage conditions, starter cultures and virulence of pathogens influenced the reproduction of $L$. monocytogenes in cheese (Kovincic et al., 1991). The high incidence of these organisms in different types of cheeses may be accounted for by insufficient hygiene during milking, manufacturing process, ineffective pasteurization and/or post pasteurization contamination.

The absence of Listeria spp. in Talaga cheese could be attributed to the presence of undesirable conditions during cheese manufacturing process such as high concentration of sodium chloride, low acidity, heat treatment and high moisture content and /or preservation in salted whey (Zamani-Zadeh et al., 2011).

High incidence of Listeria spp. In Kareish cheese and butter milk cheese may be revealed to traditional homemade manufacturing technique utilized, whereas separating milk for Kareish cheese and the collection of butter milk cheese from butter churn are steps difficult to be controlled besides these cheeses don't contain salt content nor preserved in brine solution as to Talaga cheese. 
Yoghurt is one of the most popular fermented dairy products which has a wide acceptance worldwide. In the present study, none of the yoghurt samples was found to contain Listeria spp. which may be attributed to antagonistic activity of starter and effective heat treatment Arquez et al. (2005) and Vermeulen et al. (2007).

The results obtained in the current study are almost similar to those of Arslan and Ozdemir (2008); AbdElAal and Atta (2009); Rahimi et al. (2012); Ismail et al. (2014); Metwally and Ali (2014); Shamloo et al. (2015).

While studies performed by Shahbazi et al. (2013); Muhammed et al. (2013); Seyoum et al. (2015) L.monocytogenes was detected in only one sample.

In study of Faleiro et al. (2003) revealed absence of L.monocytogenes in all examined samples of Iranian fermented milk drink to the combined inhibitory effect of low $\mathrm{pH}$ and the antimicrobial activity of some compounds that probably secreted by lactic acid bacteria present in these fermented products.

\section{Detection of Listeria monocytogenshly A gene by using PCR technique:}

Molecular biology method basedon Polymerase chain reaction (PCR) assay was characterized by high specificity, sensitivity, rapidity and it may permit direct detection of pathogen without need for isolation of pure culture (Zhou and Jiao 2005).

Thus, this study was attempted for further confirmation of L. monocytogenes isolates through the detection of one of its virulence factors. PCR was carried out targeting the virulence factor Listeriolysin O (LLO) which encoded by hlyA gene and present only in virulent strains of the species and required for virulence Jay, (1996); Ueda et al. (2005); Aurora et al. (2007); Suriyapriya et al. (2016).

In this study, the result of PCR technique was represented in Table 3 and Figure 3 confirmed the presence of L.monocytogenes in 2(5\%), 3(7.5\%), $2(5 \%)$ and $1(2.5 \%)$ of fresh cream, ice cream, butter milk cheese and Kareish cheese samples, respectively.

Abd El Tawab et al. (2015) detected that the (hlyA) gene was amplified in 5(100\%) L.monocytogenes strains. Also Nayak et al. (2015) detected virulence listeriolysin $\mathrm{O}$ (hlyA) gene in the all three L.monocytogenes which isolated from raw milk samples.

In a study conducted by Al Ashmawy et al. (2014) Enrichment PCR investigated hly A gene in 28 and 32 of the examined Damietta cheese and Kareish cheese, respectively. In another study performed by
Wijendra et al. (2014) L.monocytogenes was positively detected by using PCR technique in $10(12 \%), 8(10 \%), 4(5 \%)$ and $3(4 \%)$ of ice cream, curd, cheese and yoghurt samples respectively, while Derra et al. (2013) reported that only one sample $(1.7 \%)$ of cottage cheese was positive for L.monocytogenes by PCR.

PCR results showed that detection of virulent (hlyA) gene of L. monocytogenes which present only in the virulent strains in fresh cream, ice cream, Kareish cheese and butter milk cheese suggested the presence of a significant public health hazard linked to the consumption of these products.

\section{CONCLUSION}

This study indicates that some dairy products sold in Beni-suef markets may be considered as a threat to consumers. They are significant vehicles of $L$. monocytogenes which regularly causing listeriosis outbreaks. Therefore clear risk factors and people that are susceptible for acquiring listeriosis should not consume such products. This indicates importance and need for permanent control, and detection of potential sources of contamination. Introduction of HACCP (Hazard Analysis and Critical Control Points), as away of control in the process of production and processing the risk of contamination of products with these pathogen micro organisms is reduced.

\section{REFERENCES}

Abd El Aal, S.F.A. and Atta, M.A.H.B. (2009): Occurrence of Listeria and Yersinia species in milk and some milk products. Assuit Vet. Med. J., 55(123):45-60.

Abd El-Tawab, A.A.; Maarouf, A.A.A. and Mahy, Z.A.M. (2015): Bacteriological and Molecular studies of Listeria species in milk and milk products at El-Kaliobia Governorate, Benha. Veterinary Medical J., 29(2):170-180.

Ahmed, Hanaa, S. (2013): Public health significance of Listeria as a food borne pathogen. M.V. Sci. Thesis, Faculty. Vet. Med. Cairo Univ., Egypt.

Ahmed, L.I.; Morgan, S.D.; Hafez, R.S. and AbdelAll, A.A.A. (2014): Influence of yoghurt starter culture on viability of some pathogenic microorganisms in yoghurt. Int. J. Dairy Sci., 9(3): 82-88.

Akya, A.; Najafi, F.; Moradi, J.; Mohebi, Z. and Adabagher, S. (2013): Prevalence of food contamination with Listeria spp. in Kermanshah, Islamic Republic of Iran. Eastern Mediterranean Health J., 19(5): 474-477.

Al-Ashmawy, Maha, A.M.; Gwida, Mayada, M. and Abdelgalil, K.H. (2014): Prevalence, detection 
methods and antimicrobial susceptibility of listeria monocytogenes isolated from milk and soft cheeses and its zoonitic importance. World Applied Sciences J., 29(7): 869-878.

Ambily, A. and Beena, A.K. (2012): Bacteriological quality of ice cream marketed in Thrissur town, Kerala, India. Vet. World J., 5(12): 738741.

Anonymous, (2012): Over 50 children took ill; food poisoning suspected. The Hindu on the Web. 1 March 2012.

Arques, J.L.; Rodriguez, E.; Gaya, P.; Medina and Nunez, M. (2005): Effect combinations of high pressure treatment and bacteriocin producing lactic acid bacteria on the survival of L.monocytogenes in raw milk cheese. Int. Dairy J., 15:893-900.

Arslan, S. and Ozdemir, F. (2008): Prevalence and antimicrobial resistance of Listeria spp. in homemade white cheese. Food Control., 19(11): 360-363.

Atil, E.; Ertas, H.B. and Ozbey, G. (2011): Isolation and molecular characterization of Listeria spp. from animals, food and environmental samples. Veterniary Medicine., 56(8): 386394.

Aureli, P.; Fiorucci, G.C.; Caroli, D.; Marchiaro, G.; Novara, O.; Leone, L. and Salmaso, S. (2000): An outbreak of febrile gastroentroenteritis association with corn contamination by L.monocytogenes. New Engl. J. Med., 342: 1236-1241.

Aurora, Ritu; Prakash, A. and Prakash, S. (2007): A comparative study of conventional culture and PCR method for the detection of L.monocytogenes from artificially inoculated milk. Ind. J. of Dairy Sci., 60: 331-337.

Begley, M.; Cotter, P.D.; Hill, C. and Ross, R.P. (2010):

Glutamatedecarboxylasemediatednisinresistancein L.monocytogenes. Appl. Environ. Microbiol. 76: 6541-6546.

CDC (Centers for Disease Control and prevention) (2011): Multistate outbreak of listeriosis associated with Jensen farms cantaloupeUnited States, Augest - September 2011. Morbidity and Mortality Weekly Report, 60: 1357-1358.

Cheng, C.; Yang, Y.; Dong, Z.; Wang, X.; Fang, C.; Yang, M.; Sun, J.; Xiao, L.; Fang, W. and Song, H. (2015): L. monocytogenes varies among strains to maintain intra cellular $\mathrm{pH}$ homeostasis under stresses by different acids as analyzed by a high throughput microplate based fluorometry. Frontiers in Microbiology. $6(15)$.

Cocolin, L.; Stellab, T.S.; Nappic, R.; Bozzettac, E.; Cantonib, C. and Comi, G. (2005): Analysis of PCR- based methods for characterization of L.monocytogenes strains isolated from different sources. Int. J. Food Microbiology, 103, 167-178.

Derra, F.A.; Karlsmose, S.; Monga, D.P.; Mache, A.; Svendsen, C.A.; Felix, B.; Granier, S.A.; Geyid, A.; Taye, G. and Hendriksen, R.S. (2013): Occurrence of Listeria spp. in retail meat and dairy products in the area of Addis Ababa, Ethiopia. Foodborne Pathogens and Disease, 10(6): 577-579.

Dhanashree, B.; Otta, S.K.; Karunasagar, I.; Goebel, W. and Karunasagar, I. (2003): Incidence of Listeria spp. in clinical and food samples in Mangalore, India. Food Microbiology., 20: 447-453.

El-Habib, F.; Mustapha, M.E.; El-Quardi, A.E. and Senouci, S. (2014): L. monocytogenes in food matrix: Frequency and effect of antagonist microbiology. Pakistan J. Nutrition., 13(3): 141-145.

El-Marnissi, B.; Bennani, L.; Cohen, N.; Lalami, A.E. and Belkhou, R. (2013): Presence of L.monocytogenes in raw milk and traditional dairy products marketed in the north -central region of Morocco. African J. Food Science. 7(5): 87-91.

Faleiro, M.L.; Andrew, P.W. and Power, D. (2003): Stress response of L. monocytogenes isolated from cheese and other foods. Int. J. Food Microbiol., 84: 207-216.

Farber, J.M.; Carter, A.O.; Varughese, P.V.; Ashton, F.E. and Ewan, E.P. (1990): Listeriosis traced to the consumption of alfalfa tablets and soft cheese. New England J. Medicine., 322, 338.

Fox, P.F.; McSweeney, P.L.H.; Cogan, T.M. and Guinee, T.P. (2004): Cheese: Chemistry, Physics and Microbiology, 3rd ed., Elsevier Academic Press, California.

Gandhi, M. and Chikindas, M.L. (2007): Listeria: A foodborne pathogen that knows how to survive. Int. J. Food Microbiol., 113, 1-15.

Gaulin, C.; Ramasay, D. and Bekal, S. (2012): Widespread listeriosis outbreak attributed to pasteurized cheese, which led to extensive cross-contamination affecting cheese retailers, Quebec, Canada, 2008. J. Food Protection. 75:71-78.

Gilot, P. and Content, J. (2002): Specific identification of L.welshimeri and L.monocytogenes by PCR assays targeting a gene encoding a fibronection - binding protein. J. Clin. Microbiol., 40 : 698-703.

Gougouli, M.; Angelidis, A.S. and Koutsoumanis, K. (2008): A study on the kinetic of L.monocytogenes in ice cream stored under static and dynamic chilling and freezing conditions. J. Dairy Science., 91: 523-530.

Goulet, V.; Jacquet, C.; Vaillant, V.; Rebiere, I.; Mouret, E.; Larente, C.; Maillot, E.; Stainer, F. and Rocourt, J. (1995): Listeriosis from 
consumption of raw milk cheese. Lancet., 345: 1581-1582.

Gunasena, D.K.; Kodikara, C.P.; Genepola, K. and Widanapathirana, S. (1995): Occurrence of L.monocytogenes in food in Sri Lanka. J. Natn. Sci. Coun. Sri Lanka. 23(3): 107-114.

Ismaiel, A.A.; Ali, E.A. and Enan, G. (2014): Incidence of Listeria in Egyptian Meat and Dairy samples. Food Sci. Biotechnol., 23(1): 179-185

Jay, J. (1996): Modern food Microbiology. In: Heldman DR, Editor. Foodborne Listeriosis. New York: Chapman and Hall, pp: 478-506.

Kasalica, A.; Vukovie, V.; Vranjes, A. and Memisi, N. (2011): L.monocytogenes in milk and dairy products. Bacteriology in Animal Husbandry., 27(3): 1067-1082.

Kells, J. and Gilmour, A. (2004): Incidence of L.monocytogenes in two milk processing enviromentsand assessment of $L$. monocytogenes blood agar for isolation. Int. J. Food Microbiol., 91:167-174.

Kevenk, T.O. and Gulel, G.T. (2016): Prevalence, antimicrobial resistance and serotype distribution of L.monocytogenes isolated from raw milk and dairy products. J. Food Safety., 36:11-18.

Kovincic, I.; Vujicic, F.I.; Švabic-Vlahovic, M.; Vulic, M.; Gagic, M. and Wesley, V.I. (1991): Survival of L.monocytoenes during the manufactureand ripening of trappist cheese. J. Food Protect., 54, 6, 418-420.

Leite, P.; Rodriguez, R.; Ferreira, M.; Ribeiro, G.; Jacquet, C.; Martin, P. and Brito, L. (2006): Comparative characterization of $L$. monocytogenes isolated from Portuguese farm house ewe' cheese and from humans. Int. J. Food Microbiology., 106: 111-121.

Liu, D. (2008): Epidemiology. In D. Liu (Ed.) Handbook of L.monocytogenes (pp.27-30). New York: CRC Press.

McLauchlin, J.R.; Mitchell, W.; Smerdon, and Jewell, K. (2004): L. monocytogenes and listeriosis: A review of hazard characterization for use in microbiological risk assessment of foods. Int. J. Food Microbiol., 92: 15-33.

Mengesha, D.; Zewde, B.M.; Toquin, M.T.; Kleer, J.; Hildebrandh, G. and Gebreyes, W.A. (2009): Occurrence and distribution of L.monocytogenes and other Listeria species in ready- to-eat and raw meat products. Berl. Munch. Tierarztl. Wochenschr., 122 (1-2_:2024.

Meshref, A.M.S.; Zeinhom, M.M.A. and Abdel-Atty, N.S. (2015): Occurrence and distribution of Listeria species in some Egyptian foods. Alexandria. J. Vet. Sci., 46: 42-47.

Metwally, A.M.M. and Ali, Fatma, H.M. (2014): Listeria spp. in ready -to-eat dairy products from retailers and small shops. J. Food and Dairy Sci. Mansoura Univ., 5(10): 725-730.

Molla, B.; Yilma, R. and Alemayehu, D. (2004): L. monocytogenes and other Listeria species in retail meat and milk products in Addis Ababa, Ethiopia. Ethiop. J. Health Dev., 18(3): 208212.

Muhammed, Wosila; Muleta, D.; Deneke, Y.; Gashaw, A. and Bitew, M. (2013): Studies on occurrence of L. monocytogenes and other species in milk and milk products in retail market of Jimma Town, Ethiopia. Asian J. Dairying and Food Research., 32(1): 35-39.

Nayak, D.N.; Savalia, C.V.; Kalyani, I.H.; Kumar, R. and Kshirsagar, D.P. (2015): Isolation, identification and characterization of Listeria spp. from various animal origin foods .Vet. World.,8(6): 695-701.

Oliver, S.P.; Jayarao, B.M. and Almeida, R.A. (2005): Food-borne pathogens in milk and the dairy farm environment: Food safety and public health implications. Foodborne Pathog. Dis., 2: 115-129.

Olszewska, M.A.; Panfil-Kuncewicz, H. and Eaniewska-Trokenheim, L. (2015): Detection of viable but nonculturable cells of $L$. monocytogenes with the use of directepifluorescent filter technique. J. Food Safety.,35: 86-90.

Rahimi, E.; Ameri, M. and Momtaz, H. (2010): Prevalence and antimicrobial resistance of Listeria species isolated from milk and dairy products in Iran. Food Control 21: 1448-1452.

Rahimi, E.; Momtaz, H.; Sharifzadeh, A.; Behzadnia, A.; Ashtari, M.S.; Zandi Esfahani, S.; Riahi, M. and Momeni, M. (2012): Prevalence and antimicrobial resistance of Listeria species isolated from traditional dairy products in Chahar Mahal and Bakhtiyari, Iran. Bulgarian J. Vet. Medicine., 15(2):115-122.

Roberts, A.J. and Weidmann, M. (2003): Pathogen, host and environment factors contributing to the pathogensis of listeriosis. Cell Mol. Life Sci., 60: 904-918.

Roberts, D. and Greenwood, M. (2003): Practical Food Microbiology., 3rd edition, by Black well Publishing Ltd, USA.

Rosshaug, P.S.; Detmer, A.; Ingmer, H. and Larsen, M.H. (2012): Modeling the growth of L.monocytogenes insoft blue-white cheese. Appl. Environ. Microbiol., 78:8508-8514.

Ryser, E.T. and Marth, E. (2007): Listeria, Listeriosis and Food Safety.3rd.Ed.Taylor and Francis. Boca Raton, Fl.

Seyoum, E.T.; Woldetsadik, D.A.; Mekonen, T.K.; Gezahegn, H.A. and Gebreyes, W.A. (2015): Prevalence of Listeria in raw bovine milk and milk products from central highlands of Ethiopia. J. Infect. Dev. Ctries., 5(11): 12041209. 
Shahbazi, A.M.; Rashedi, M. and Sohrabi, R. (2013): Comparative contamination of L.monocytogenes in traditional dairy products in Esfahan province, Iran. African J. Microbiology Research.,7(16):1522-1526.

Shamloo, E.; Jalali, M.; Mirlohi, M.; Madani, G.; Metcalf, D. and Merasi, M.R. (2015): Prevalence of Listeria spp. In raw milk and traditional dairy products in Isfahan, Iran. Int. J. Environmental Health Engineering., 4:1.

Suriyapriya, S.; Selvan, P.; Porteen, K. and Suresh, S.K. (2016): Prevalence of Listeria spp. in traditional Indian dairy products from Chennai Metropolis, Tamil Nadu. International Conference of Sabaragamuwa University of Sri-lanka 2015. Procedia Food Science.,6: 230234.

Swaminathan, B. and Gerner-Smidt, P. (2007): The epidemiology of human listeriosis "Microbes and Infection "., Vol. 9 (10): 1236-1243.

Swaminathan, B.; Cabanes, D.; Zhang, W. and Cossart, P. (2007): L.monocytogenes. In Food Microbiology Fundamentals and Frontiers, 3rd ed. (M.P. Doyle and L.R. Beuchat, eds.) pp: 457-491, American Society for Microbiology (ASM) Press., Washington DC.

Ueda, F.; Anahara, R.; Yamada, F.; Mochizuki, M.; Ochiai, Y. and Hondo, R. (2005):
Discrimination of L. monocytogenes contaminated commercial Japanese meats. Int. J. Food Microbiology., 15: 455-462.

Vermeulen, A.; Gysemans, K.P.M.; Bernaerts, K.; Geeraerd, A.H.; Van Impe, J.F.; Debevere, J. and Devlieghere, F. (2007): Influence of $\mathrm{pH}$, water activity and acetic acid concentration on L.monocytogenes at $7^{\circ} \mathrm{C}$ : Data collection for the development of a growth/no growth model. Int. J. Food Microbiol., 114: 332-341.

Wahba, Nahed, M. (2002): Studies on Listeria species in milk and some milk products in Assuit Governorate. Ph. D. Thesis. Faculty of Vet. Med., Assuit University. Egypt.

Wijendra, W.A.S.; Kulathunga, K.A.K.C. and Ramesh, R. (2014): First report of $L$. monocytogenes serotypes detected from milk and milk products in Sri Lanka. Adv.Anim.Vet.Sci.,2(55):11-16.

Zamani-Zadeh, M.; Sheikh-Zeinoddin, M. and Soleimanian-Zad, S. (2011): Prevalence and characterization of Listeria species in domestic and industrial cheeses of Isfahan Region. Iranian J. Publ. Health., 40(3): 98-104.

Zhou, X. and Jiao, X. (2005): Polymerase Chain Reaction detection of $L$. monocytogenes using oligonucleotide primers targeting actA gene. Food Control., 16(2): 125-130.

\section{مدى تواجد انواع الليستيريا فى بعض منتجات الالبان فى محافظة بنى سويف \\ سعديه طمى حسبن الثناوى ، عرفه مشرف سليمان مشرف ، محمد معروف على زينهم ، داليا عبل الحافظ /حمد حافظ}

Email: dalia_hafez@yahoo.com Assiut University web-site: www.aun.edu.eg

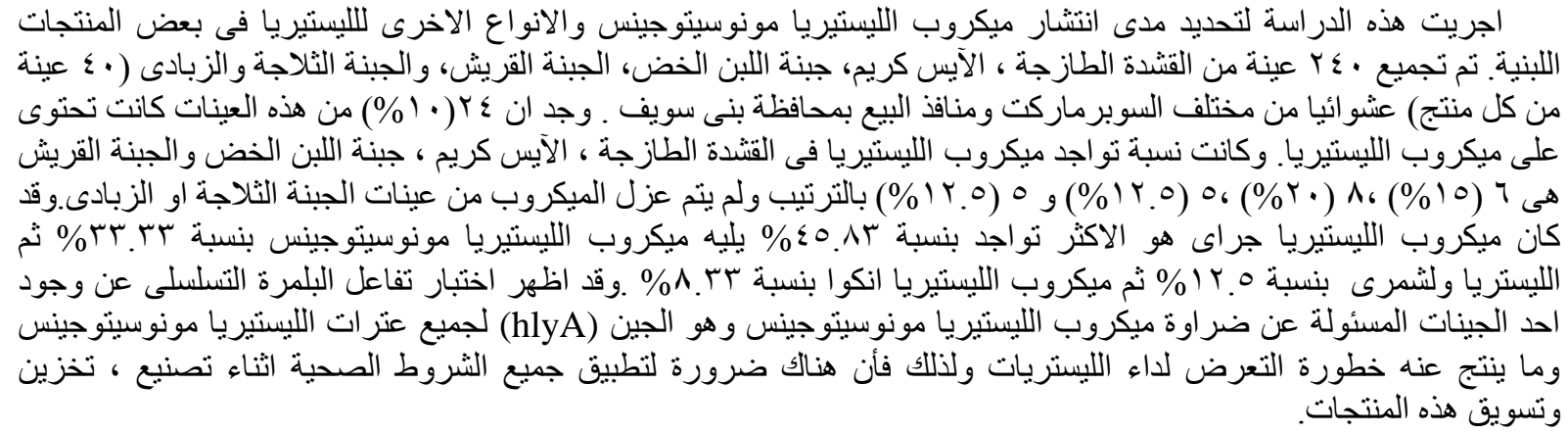

